\title{
Dental implants and diabetes mellitus-a systematic review
}

\author{
Hendrik Naujokat, Burkhard Kunzendorf and Jörg Wiltfang
}

\begin{abstract}
Dental implant surgery has developed to a widely used procedure for dental rehabilitation and is a secure and predictable procedure. Local and systemic risk factors can result in higher failure rates. Diabetes mellitus is a chronic disease that goes in with hyperglycemia and causes multifarious side effects. Diabetes as a relative contraindication for implant surgery is controversially discussed. Because the number of patients suffering from diabetes increases, there are more diabetic patients demanding implant procedures. We aimed to answer the PICO question "Do diabetic patients with dental implants have a higher complication rate in comparison to healthy controls?" by a systematic literature search based on the PRISMA statement. We identified 22 clinical studies and 20 publications of aggregated literature, which were quite heterogeneous concerning methods and results. We conclude that patients with poorly controlled diabetes suffer from impaired osseointegration, elevated risk of peri-implantitis, and higher level of implant failure. The influence of duration of the disease is not fully clear. The supportive administration of antibiotics and chlorhexidine seems to improve implant success. When diabetes is under well control, implant procedures are safe and predictable with a complication rate similar to that of healthy patients.
\end{abstract}

Keywords: Dental implants, Implant survival, Diabetes mellitus, Glycemic control, Peri-implantitis, Systemic disease, Risk factor

\section{Review} Introduction

Today, dental implants are one of the restorative methods to replace missing teeth. Improvements in implant design, surface characteristics, and surgical protocols made implants a secure and highly predictable procedure with a mean survival rate of $94.6 \%$ and a mean success rate of $89.7 \%$ after more than 10 years [1]. Implant survival is initially dependent on successful osseointegration following placement. Any alteration of this biological process may adversely affect treatment outcome. Subsequently, as an implant is restored and placed into function, bone remodeling becomes a critical aspect of implant survival in responding to the functional demands placed on the implant restoration and supporting bone. The critical dependence on bone metabolism for implant survival leads us to evaluation of certain risk factors. One of the controversial discussed diseases is diabetes mellitus.

\footnotetext{
* Correspondence: naujokat@mkg.uni-kiel.de

Klinik für Mund- Kiefer- und Gesichtschirurgie, Universitätsklinikum

Schleswig-Holstein, Campus Kiel, Arnold-Heller-Straße 3, 24105 Kiel, Germany
}

Diabetes mellitus is a chronic metabolic disorder that leads to hyperglycemia, which raises multiple complications caused by micro- and macroangiopathy. Diabetic patients have increased frequency of periodontitis and tooth loss [2], delayed wound healing [3], and impaired response to infection. In 1980, more than 150 million people worldwide were affected and that number had grown to 350 million by 2008 [4]. This trend highlights the need for better understanding of diabetes and its therapy and its impact on dental implant rehabilitation. In the past, diabetes was long time seen as a relative risk factor to dental implants. In contrast, today, there is a change in paradigm. Recent studies offer indirect evidence for diabetes patients benefiting from oral rehabilitation based on dental implant therapy. After tooth loss, patients avoid food which needs more effort to masticate which can lead to an adverse nutrition with poor metabolic control. A sufficient dental rehabilitation allows the patient to improve nutrition and the metabolic control. On the other hand, it is still unclear how quality of diabetes therapy and duration of disease influence the
焦 Springer

(c) 2016 Naujokat et al. Open Access This article is distributed under the terms of the Creative Commons Attribution 4.0 International License (http://creativecommons.org/licenses/by/4.0/), which permits unrestricted use, distribution, and reproduction in any medium, provided you give appropriate credit to the original author(s) and the source, provide a link to the Creative Commons license, and indicate if changes were made. 
success of dental implants. The ability to anticipate outcomes is an essential part of risk management in dental implant surgery. Recognizing conditions that place the patient at a higher risk of complications will allow the surgeon to make informed decisions and refine the treatment plan to optimize the outcomes [5].

Therefore, we conducted a systematic review of published clinical studies to investigate whether dental implant placement in diabetic vs. non-diabetic patients yields any detrimental effects on postoperative complications, peri-implantitis, and implant failure rate. The main goal is to get a more detailed view on the influence of quality of glycemic control and duration of disease to give recommendation for treatment options and surgical protocols.

\section{Materials and methods}

The substructure of the systematic review is based on the PRISMA statement [6]. The focused question according to the PICO schema is: "Do diabetic patients with dental implants have a higher complication rate in comparison to healthy controls?"

\section{Search strategies}

The systematic literature search was performed by an independent scientist (Burkhard Kunzendorf). The following databases were incorporated in the systematic search for relevant literature: PubMed, Embase, AWMF Online, National Guideline Clearinghouse, Guidelines International Network, and Cochrane Library. The following search terms were used: dental implants AND diabetes, transgingival implants AND diabetes, maxillary augmentation AND diabetes, mandibular augmentation AND diabetes, peri-implantitis AND diabetes, Zahnimplantate AND Diabetes, Kieferkammaufbau AND Diabetes, Periimplantitis AND Diabetes. Electronic search was complemented by an iterative hand-search in the reference lists of the already identified articles. The time period of the literature search was between 10 April and 7 May 2015. Endnote X7 was used for the electronic management of the literature.

\section{Study inclusion and exclusion criteria}

During the first stage of study selection, the titles and abstracts were screened and evaluated according to the following inclusion criteria: English or German language, retrospective and prospective clinical trials, observational studies, cross-sectional studies, cohort studies, and case series. During this procedure, the pre-selected publications were evaluated according to the following exclusion criteria: in vitro studies, animal studies, case reports with less than 10 patients, and publications older than 15 years.

\section{Quality and risk of bias assessment of selected studies}

A quality assessment of all selected full-text articles was performed. It made no sense to use the Cochrane collaboration tool for assessing risk of bias for randomized controlled studies since the majority of the included studies were not randomized or retrospective case series. Instead, a system modified from the US Agency for Healthcare Research and Quality Methods Guide for Comparative Effectiveness Reviews was used, which asked for the sources of possible bias [7]. The criteria were each judged with low, medium, high, or unknown risk of bias: case selection bias and confounding, attrition bias (loss of participants), detection bias (reliable measures), and reporting bias (selective or incomplete reporting), followed by a summary of the risk.

\section{Results}

\section{Study selection}

There are no guidelines existing to the topic of dental implants and diabetes mellitus. A total of 327 potentially relevant titles and abstracts were found by the electronic search and additional evaluation of reference lists. During the first screening, 230 publications were excluded based on the title and keywords. Additionally, 24 titles were excluded based on abstract evaluation. Seventythree full-text articles were thoroughly evaluated. A total of 51 papers had to be excluded at this stage because they did not fulfil the inclusion criteria of the present systematic review. Twenty-two articles went into qualitative assessment (Fig. 1). Because of too few studies, heterogenic study design, and incompletely reported data like type of diabetes therapy, quality of glycemic control, and duration of disease, the quantitative data synthesis could not be performed in the way necessary for metaanalysis. Additionally, we identified 20 reviews and meta-analyses. They are excluded from our results.

\section{Evaluation of study quality and risk of bias}

The majority $(n=12)$ of the 22 studies were prospective and one of these studies was a multicenter study. Eight were retrospective and two were cross-sectional studies. Randomization of patients was not readable in any of the studies (Table 1). Despite a low evidence level in terms of study design, there were no major concerns about risk of bias; 13/22 studies were rated with a low risk of bias, 9/22 had a medium risk. No study had a high risk of bias, and consequently no further study was excluded at this stage because of bias (Table 2).

\section{Diabetes and osseointegration}

Osseointegration describes the process of formation of a direct interface between the implant and bone, without intervening soft tissue. This process is prerequisite for implant stability and inflammation-free survival. It includes 


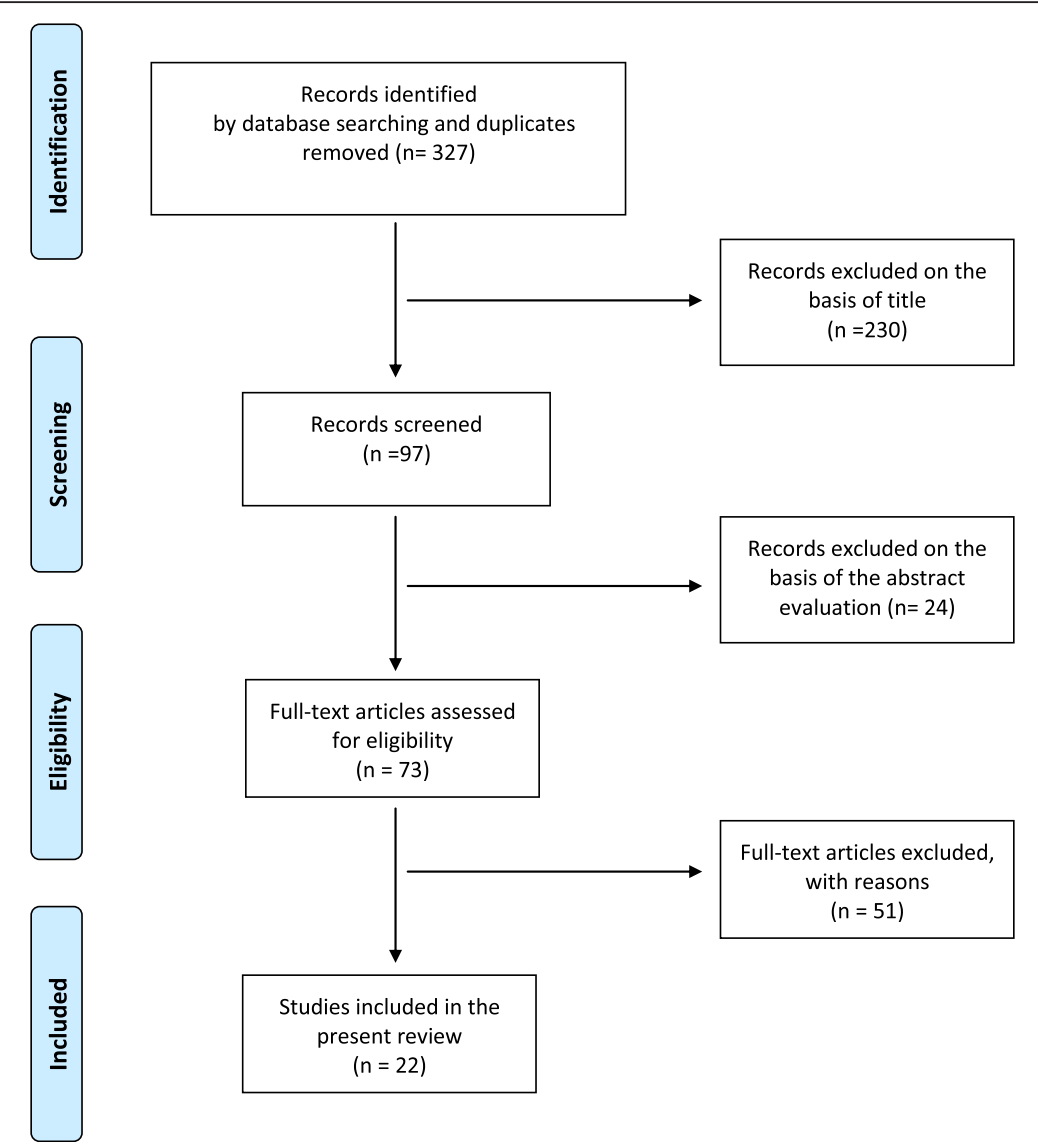

Fig. 1 Selection process of the included literature

remodeling of the surrounding bone with migrations and proliferation of osteoblasts and supporting connective tissue. We identified two prospective studies investigating the influence of type II diabetes on osseointegration. They are published by the same author but are independent studies from different years $[8,9]$. In both studies, the patients included were stratified by $\mathrm{HbA} 1 \mathrm{c}$ levels as well-controlled (HbA1c 6.1-8 \%), moderately controlled (HbA1c 8.1$10 \%$ ), and poorly controlled (HbA1c $\geq 10 \%$ ). The healthy control had HbA1c $\leq 6 \%$. Patients with poorly controlled diabetes have lower stability at the first 2 to 6 weeks. In the following weeks, stability reaches the baseline again, but reaching baseline takes two times the duration it needs in the healthy treatment group. Looking at the implant stability 1 year after implantation, there is no difference between the groups, not even to the poorly controlled HbA1c.

\section{Diabetes and peri-implantitis}

We found two prospective, two cross-sectional, and one retrospective study examining the influence of diabetes on peri-implantitis. The conclusions are quite heterogeneous. The study of Aguilar-Salvatierra [10] started to evaluate 2 years after insertion and found that the number of patients suffering from peri-implant inflammation increases with elevated $\mathrm{HbA1c}$ values. The population was divided into well-controlled (HbA1c 6-8 \%), moderately controlled (HbA1c 8-10\%), and poorly controlled (HbA1c $>10 \%)$, but there was no healthy control. The two cross-sectional studies yield an elevated relative risk for peri-implantitis of 1.9 and 4.1 caused by diabetes [11, 12]. The duration of these studies was 6 months to 5 years and 10 years, respectively. On the other hand, the retrospective study of Turkyilmaz [13] showed no evidence of diminished clinical success 1 year after implantation, defined by negative bleeding on probing, no pathological probing depth, and a marginal bone loss of $0.3 \pm 0.1 \mathrm{~mm}$ in a population of type II diabetics. The results in the prospective study of Gomez-Moreno [14] show that elevated HbA1c causes more bone resorption after 3 years, but this effect is not significant. The bleeding on probing is more often in the poorly controlled population, but the probing depth is not increased.

\section{Diabetes and implant survival}

Implant survival is an easily defined and measured endpoint for dental implant therapy. Nearly every study reports its implant survival rate. Our literature search identified 18 publications with these data. We divided 
Table 1 List of the included studies and its main characteristics

\begin{tabular}{|c|c|c|c|c|c|c|c|c|c|c|c|c|}
\hline Author & Year & Study type & $\begin{array}{l}\text { Diabetes } \\
\text { type }\end{array}$ & Control & $\begin{array}{l}\text { Diabetes } \\
\text { therapy }\end{array}$ & $\begin{array}{l}\text { Glycemic } \\
\text { control } \\
\text { [HbA1c \%] }\end{array}$ & $\begin{array}{l}\text { Duration } \\
\text { of diabetes } \\
\text { (years) }\end{array}$ & $\begin{array}{l}\text { Number of } \\
\text { patients }\end{array}$ & $\begin{array}{l}\text { Number of } \\
\text { implants }\end{array}$ & $\begin{array}{l}\text { Duration } \\
\text { of study } \\
\text { (years) }\end{array}$ & $\begin{array}{l}\text { Implant } \\
\text { survival [\%] }\end{array}$ & Conclusion \\
\hline Alsaadi & 2007 & Retrospective & Type II & $\begin{array}{l}\text { Non- } \\
\text { diabetes }\end{array}$ & n.d. & n.d. & n.d. & $\begin{array}{l}2004 \\
\text { (overall) }\end{array}$ & $\begin{array}{l}6946 \\
\text { (overall) }\end{array}$ & 6 months & $\begin{array}{l}96.4 \\
\text { (global) }\end{array}$ & $\begin{array}{l}\text { Diabetes does not cause higher } \\
\text { failure rate in the first } 6 \text { months. }\end{array}$ \\
\hline $\begin{array}{l}\text { Aguilar- } \\
\text { Salvatierra }\end{array}$ & 2015 & Prospective & Type II & $\begin{array}{l}3 \text { groups } \\
\text { (HbA1c) }\end{array}$ & n.d. & $\begin{array}{l}\text { 6-8 (well), 8-10 } \\
\text { (moderately), } \\
>10 \text { (poorly) }\end{array}$ & n.d. & 85 & 85 & 2 & $\begin{array}{l}100 \text { vs. } 96.6 \\
\text { vs. } 86.3\end{array}$ & $\begin{array}{l}\text { Patients with diabetes can receive } \\
\text { implant-based treatments, } \\
\text { providing they present moderate } \\
\text { HbA1c values. Peri-implantitis } \\
\text { increases with elevated HbA1c. }\end{array}$ \\
\hline Anner & 2010 & Retrospective & n.d. & $\begin{array}{l}\text { Non- } \\
\text { diabetes }\end{array}$ & n.d. & n.d. & n.d. & $\begin{array}{l}49 \text { diabetes, } \\
475 \text { overall }\end{array}$ & 1626 & $3 \pm 2$ & 97.2 vs. 95 & $\begin{array}{l}\text { Diabetes was not related to implant } \\
\text { survival in this patient cohort. }\end{array}$ \\
\hline Busenlechner & 2014 & Retrospective & n.d. & $\begin{array}{l}\text { Non- } \\
\text { diabetes }\end{array}$ & n.d. & n.d. & n.d. & 4316 & $>10,000$ & 8 years & 95.1 vs. 97 & $\begin{array}{l}\text { Diabetes does not have any } \\
\text { influence on implant survival after } \\
8 \text { years, if blood sugar is effectively } \\
\text { controlled. }\end{array}$ \\
\hline Daubert & 2015 & $\begin{array}{l}\text { Cross- } \\
\text { sectional }\end{array}$ & n.d. & $\begin{array}{l}\text { Non- } \\
\text { diabetes }\end{array}$ & n.d. & n.d. & n.d. & $\begin{array}{l}8 \text { diabetes, } \\
96 \text { overall }\end{array}$ & 225 & 10 & n.d. & $\begin{array}{l}\text { Significant associations between } \\
\text { implant failure and diabetes (relative } \\
\text { risk } 4.8 \text { and 3.3) and peri-implant } \\
\text { diseases and diabetes (relative risk 4.1). }\end{array}$ \\
\hline Dowell & 2007 & Prospective & Type II & $\begin{array}{l}\text { Non- } \\
\text { diabetes }\end{array}$ & $\begin{array}{l}\text { Diet, oral, } \\
\text { insulin and } \\
\text { combination }\end{array}$ & $\begin{array}{l}\text { 6-8 (well), 8-10 } \\
\text { (moderately), } \\
>10 \text { (poorly) }\end{array}$ & n.d. & $\begin{array}{l}25 \text { diabetes, } 10 \\
\text { non-diabetes }\end{array}$ & $\begin{array}{l}38 \text { diabetes, } \\
12 \text { non- } \\
\text { diabetes }\end{array}$ & 4 months & 100 & $\begin{array}{l}\text { Diabetes has no negative influence; } \\
\text { the quality of glycemic control has } \\
\text { no effect on implant success. }\end{array}$ \\
\hline Erdogan & 2014 & Prospective & Type ॥ & $\begin{array}{l}\text { Non- } \\
\text { diabetes }\end{array}$ & n.d. & Mean 6.8 & 7.5 & $\begin{array}{l}12 \text { diabetes, } \\
12 \text { control }\end{array}$ & 43 & 1 & 100 & $\begin{array}{l}\text { No significant difference for wound } \\
\text { healing, radiographic findings, } \\
\text { implant success and volume of } \\
\text { augmentation (guided bone } \\
\text { regeneration with bone scrapes } \\
\text { and bone substitute material). }\end{array}$ \\
\hline Ferreira & 2006 & $\begin{array}{l}\text { Cross- } \\
\text { sectional }\end{array}$ & n.d. & $\begin{array}{l}\text { Non- } \\
\text { diabetes }\end{array}$ & n.d. & $\begin{array}{l}\text { Blood sugar } \\
>126 \mathrm{mg} / \mathrm{dl} \\
\text { or diabetic } \\
\text { medication } \\
\text { subscribed }\end{array}$ & n.d. & 212 (overall) & 578 (overall) & $\begin{array}{l}6 \text { months- } \\
5 \text { years }\end{array}$ & n.d. & $\begin{array}{l}\text { Risk for peri-implantitis in } \\
\text { "uncontrolled" diabetes is } 1.9 \text { times } \\
\text { higher compared to the non- } \\
\text { diabetes group. }\end{array}$ \\
\hline Fiorellini & 2000 & Retrospective & $\begin{array}{l}\text { Types I } \\
\text { and II }\end{array}$ & None & n.d. & $\begin{array}{l}\text { "Proper levels } \\
\text { of glycemic } \\
\text { control" }\end{array}$ & $8.9 \pm 14.3$ & 40 & 215 & 6.5 & 85.6 & $\begin{array}{l}\text { Survival rate is lower than for general } \\
\text { population, but there is still a } \\
\text { reasonable success rate. Most implant } \\
\text { failures are in the first year after } \\
\text { loading. }\end{array}$ \\
\hline Ghiraldini & 2015 & Prospective & Type II & $\begin{array}{l}\text { Non- } \\
\text { diabetes }\end{array}$ & n.d. & $\begin{array}{l}<8 \text { (better) } \\
>8 \text { (poorly) }\end{array}$ & $10.7 \pm 5$ & $\begin{array}{l}16 \text { better, } 16 \\
\text { poorly, } 19 \\
\text { control }\end{array}$ & 51 & 1 & 100 & $\begin{array}{l}\text { Poor glycemic control negatively } \\
\text { modulated the bone factors during } \\
\text { healing, although diabetes } \\
\text { (regardless of glycemic control) had } \\
\text { no effect on implant stabilization. }\end{array}$ \\
\hline $\begin{array}{l}\text { Gomez- } \\
\text { Moreno }\end{array}$ & 2014 & Prospective & Type II & $\begin{array}{l}4 \text { groups } \\
(\mathrm{HbA} 1 \mathrm{c})\end{array}$ & n.d. & $\begin{array}{l}<6 \text { (healthy) } \\
6-8 \text { (well), 8-10 }\end{array}$ & n.d. & 67 & 67 & 3 & n.d. & $\begin{array}{l}\text { Elevated HbA1c causes more bone } \\
\text { loss (not significant) and significantly }\end{array}$ \\
\hline
\end{tabular}


Table 1 List of the included studies and its main characteristics (Continued)

\begin{tabular}{|c|c|c|c|c|c|c|c|c|c|c|c|c|}
\hline & & & & & & $\begin{array}{l}\text { (moderately) } \\
>10 \text { (poorly) }\end{array}$ & & & & & & $\begin{array}{l}\text { higher BOP. Probing depth is not } \\
\text { influenced by glycemic control. }\end{array}$ \\
\hline Khandelwal & 2011 & Prospective & Type II & $\begin{array}{l}2 \text { different } \\
\text { types of } \\
\text { implants }\end{array}$ & n.d. & $\begin{array}{l}7.5-11.4 \text { (poorly } \\
\text { controlled) }\end{array}$ & n.d. & 24 & 48 & 4 months & 98 & $\begin{array}{l}\text { Successful implant therapy in patients } \\
\text { suffering poorly controlled diabetes. } \\
\text { No difference between the two } \\
\text { implant systems. }\end{array}$ \\
\hline Morris & 2005 & Prospective & Type II & $\begin{array}{l}\text { Non- } \\
\text { diabetes }\end{array}$ & n.d. & n.d. & n.d. & 663 & $\begin{array}{l}255 \text { diabetes, } \\
2632 \text { non- } \\
\text { diabetes }\end{array}$ & 3 & $\begin{array}{l}92.2 \text { and } 93.2, \\
\text { respectively }\end{array}$ & $\begin{array}{l}\text { Diabetic patients tend to have more } \\
\text { failures than non-diabetic patients. } \\
\text { The use of CHX resulted in a slight } \\
\text { improvement in survival in non- } \\
\text { diabetic patients and in a greater } \\
\text { improvement in type II patients, the } \\
\text { same effect for antibiotic use. }\end{array}$ \\
\hline Moy & 2005 & Retrospective & n.d. & $\begin{array}{l}\text { Non- } \\
\text { diabetes }\end{array}$ & n.d. & n.d. & n.d. & $\begin{array}{l}48 \text { diabetes, } \\
1140 \text { overall }\end{array}$ & $\begin{array}{l}4684 \\
\text { (overall) }\end{array}$ & up to 20 & n.d. & $\begin{array}{l}\text { Significantly increased relative risk for } \\
\text { implant failure (relative risk }=2.75 \text { ). }\end{array}$ \\
\hline Oates & 2009 & Prospective & Type II & $\begin{array}{l}\text { Non- } \\
\text { diabetes }\end{array}$ & $\begin{array}{l}\text { Diet, oral, } \\
\text { insulin and } \\
\text { combination }\end{array}$ & $\begin{array}{l}\text { 6-8 (well), 8-10 } \\
\text { (moderately), } \\
>10 \text { (poorly) }\end{array}$ & n.d. & 32 & 42 & 4 months & & $\begin{array}{l}\text { Patients with poorly controlled HbA1c } \\
\text { have lower stability in the first 2-6 } \\
\text { weeks, but it reaches the baseline in } \\
\text { the following weeks. But reaching the } \\
\text { baseline takes two times the duration } \\
\text { it needs in the non-diabetic } \\
\text { group. }\end{array}$ \\
\hline Oates & 2014 & Prospective & Type II & $\begin{array}{l}\text { Non- } \\
\text { diabetes }\end{array}$ & n.d. & $\begin{array}{l}6-8 \text { (well), }>8 \\
\text { (poorly) }\end{array}$ & n.d. & $\begin{array}{l}44 \text { well, } 19 \\
\text { poorly, } 49 \\
\text { control }\end{array}$ & 220 & 1 & 99 & $\begin{array}{l}\text { The initial implant stability is lower } \\
\text { in diabetic patient, but } 1 \text { year after } \\
\text { insertion there in so difference even } \\
\text { in the poorly controlled group. } \\
\text { Diabetes has no influence on } \\
\text { implant survival. }\end{array}$ \\
\hline Olson & 2000 & $\begin{array}{l}\text { Prospective, } \\
\text { multicenter }\end{array}$ & Type II & None & $\begin{array}{l}\text { Diet, oral, } \\
\text { insulin and } \\
\text { combination }\end{array}$ & n.d. & n.d. & 89 & 178 & 5 & 91 vs. 88 & $\begin{array}{l}\text { Implants in mandibular symphysis in } \\
\text { diabetic patient are a predictable } \\
\text { procedure. Duration of diabetes may } \\
\text { be associated with implant failure, } \\
\text { CHX improves implant survival. }\end{array}$ \\
\hline Peled & 2003 & Retrospective & Type II & None & n.d. & $\begin{array}{l}\text { "Well-controlled," } \\
\text { no data for } \\
\text { HbAlc }\end{array}$ & n.d. & 41 & 141 & 1 and 5 & 97.3 vs. 94.4 & $\begin{array}{l}\text { No correlation was found between } \\
\text { failed implants and glucose level. } \\
\text { The clinical outcome of dental } \\
\text { implants in a selected group of } \\
\text { patients with well-controlled type II } \\
\text { diabetes mellitus is satisfying and } \\
\text { encouraging. }\end{array}$ \\
\hline Tawil & 2008 & Prospective & Type II & $\begin{array}{l}\text { Non- } \\
\text { diabetes }\end{array}$ & n.d. & $\begin{array}{l}<7 \text { (well), } 7-9 \\
\text { (moderately), } \\
>9 \text { (poorly) } \\
\text { mean } 7.2\end{array}$ & n.d. & $\begin{array}{l}54 \text { diabetes, } \\
54 \text { control }\end{array}$ & $\begin{array}{l}255 \text { diabetes, } \\
244 \text { control }\end{array}$ & 1 to 12 & 97.2 vs. 98.8 & $\begin{array}{l}\text { No significant difference for implant } \\
\text { survival between the groups and no } \\
\text { difference between good and } \\
\text { medium glycemic control for bone } \\
\text { resorption. Augmentations caused } \\
\text { no complications. Duration of } \\
\text { diabetes was no confounder. }\end{array}$ \\
\hline
\end{tabular}


Table 1 List of the included studies and its main characteristics (Continued)

\begin{tabular}{|c|c|c|c|c|c|c|c|c|c|c|c|c|}
\hline Tatarakis & 2013 & Prospective & Type II & None & n.d. & Mean 7.1 & n.d. & 32 & $>32$ & 1 & n.d. & $\begin{array}{l}\text { The clinical, microbiological, salivary } \\
\text { biomarkers and psychosocial profiles } \\
\text { of patient with diabetes under good } \\
\text { control are very similar to those of } \\
\text { non-diabetes. }\end{array}$ \\
\hline Turkyilmaz & 2010 & Retrospective & Type II & None & $\begin{array}{l}\text { Diet, oral, } \\
\text { insulin and } \\
\text { combination }\end{array}$ & $5-10$ & $5-21$ & 10 & 23 & 1 & 100 & $\begin{array}{l}\text { No evidence of diminished clinical } \\
\text { success, BOP negative, no pathological } \\
\text { probing depth, marginal bone loss } \\
0.3 \pm 0.2 \mathrm{~mm} \text {. }\end{array}$ \\
\hline Zupnik & 2011 & Retrospective & n.d. & $\begin{array}{l}\text { Non- } \\
\text { diabetes }\end{array}$ & n.d. & n.d. & n.d. & n.d. & $\begin{array}{l}25 \text { diabetes, } \\
316 \text { non- } \\
\text { diabetes }\end{array}$ & 4 & 96.4 (global) & $\begin{array}{l}\text { Implant failure (explantation) is } 2.57 \\
\text { times higher for patient with diabetes } \\
\text { than patients without diabetes after } \\
4 \text { years. }\end{array}$ \\
\hline
\end{tabular}


Table 2 Risk of bias of the included studies

\begin{tabular}{|c|c|c|c|c|c|c|c|c|}
\hline Author & Year & Study type & $\begin{array}{l}\text { Selection bias } \\
\text { (homogeneity } \\
\text { and confounders) }\end{array}$ & $\begin{array}{l}\text { Performance } \\
\text { bias (fidelity } \\
\text { to protocol) }\end{array}$ & $\begin{array}{l}\text { Attrition bias } \\
\text { (loss of participants) }\end{array}$ & $\begin{array}{l}\text { Detection bias } \\
\text { (reliable measures) }\end{array}$ & $\begin{array}{l}\text { Reporting bias } \\
\text { (selective reporting } \\
\text { or conflict interests) }\end{array}$ & $\begin{array}{l}\text { Summary } \\
\text { assessment } \\
\text { risk of bias }\end{array}$ \\
\hline Alsaadi & 2007 & Retrospective & $\bar{H}$ & $\bar{U}$ & $\bar{U}$ & L & L & $L$ \\
\hline $\begin{array}{l}\text { Aguilar- } \\
\text { Salvatierra }\end{array}$ & 2015 & Prospective & $\mathrm{H}$ & L & L & L & L & L \\
\hline Anner & 2010 & Retrospective & $\mathrm{H}$ & U & U & L & L & M \\
\hline Busenlechner & 2014 & Retrospective & $\mathrm{H}$ & L & U & L & L & L \\
\hline Daubert & 2015 & Cross-sectional & $\mathrm{H}$ & L & U & L & L & $\mathrm{L}$ \\
\hline Dowell & 2007 & Prospective & $\mathrm{H}$ & L & L & L & M & M \\
\hline Erdogan & 2014 & Prospective & $\mathrm{H}$ & L & L & L & M & M \\
\hline Ferreira & 2006 & Cross-sectional & $\mathrm{H}$ & L & L & L & L & L \\
\hline Fiorellini & 2000 & Retrospective & $\mathrm{H}$ & M & U & M & L & M \\
\hline Ghiraldini & 2015 & Prospective & $\mathrm{H}$ & L & L & $L$ & L & L \\
\hline $\begin{array}{l}\text { Gomez- } \\
\text { Moreno }\end{array}$ & 2014 & Prospective & $\mathrm{H}$ & L & L & L & L & L \\
\hline Khandelwal & 2011 & Prospective & L & L & L & M & $L$ & L \\
\hline Morris & 2005 & Prospective & $\mathrm{H}$ & L & L & M & L & M \\
\hline Moy & 2005 & Retrospective & $\mathrm{H}$ & L & U & M & L & M \\
\hline Oates & 2009 & Prospective & $\mathrm{H}$ & L & L & L & L & L \\
\hline Oates & 2014 & Prospective & $\mathrm{H}$ & L & M & L & L & L \\
\hline Olson & 2000 & $\begin{array}{l}\text { Prospective, } \\
\text { multicenter }\end{array}$ & $\mathrm{H}$ & L & U & L & L & L \\
\hline Peled & 2003 & Retrospective & $\mathrm{H}$ & L & U & M & L & M \\
\hline Tawil & 2008 & Prospective & $\mathrm{H}$ & L & L & M & L & M \\
\hline Tatarakis & 2013 & Prospective & $H$ & L & L & L & L & L \\
\hline Turkyilmaz & 2010 & Retrospective & $\mathrm{H}$ & L & U & $L$ & L & L \\
\hline Zupnik & 2011 & Retrospective & $\mathrm{H}$ & $\mathrm{L}$ & U & M & $\mathrm{L}$ & M \\
\hline
\end{tabular}

$L$ low, $M$ medium, $H$ high, $U$ unknown risk of bias

them into two groups: the first one covers 7 studies with observation time up to 1 year (6 prospective, 1 retrospective studies), the second one longer periods (4 prospective, 1 cross-sectional, and 6 retrospective studies). In the short-time group, 5 of the studies had a healthy control group. The result for implant survival in diabetics is 100 to $96.4 \%$, which does not differ from the healthy control $[9,15-18]$. The 2 studies without control group report a $100 \%$ survival rate 4 months and 1 year after implantation $[13,19]$. The time periods in the long-time group differ from 1 year up to 20 years and are very heterogeneous. We found 4 prospective, 6 retrospective, and 1 cross-sectional study. Seven studies compared the diabetic survival rates to healthy population, and results are equivocal. On the one hand, survival rates of diabetics are similar to healthy control: 95.1 vs. $97 \%, 97.2$ vs. $95 \%, 92$ vs. $93.2 \%$, and 97 vs. $98.8 \%$ [20-23]. On the other hand, there are 2 studies reporting relative risk for implant failure in diabetic patients elevated to 4.8 and 2.75 , respectively [11, 24]. The studies without a healthy control present survival rates from 100 to $86 \%$ [10], 97.3 and $94.4 \%$ after 1 and 5 years [25], and 91 to $88 \%$ after 5 years [26], which are comparable to survival rates in healthy individuals. There is one work that demonstrates survival rate of $85.6 \%$ after 6 years, which is lower than that in healthy population. The most implant failures were observed in the first year after prosthetic loading [27].

\section{Diabetes and bone augmentation}

We identified two prospective studies that evaluated "advanced" implant surgery covering sinus lift procedure and guided bone regeneration. The study of Erdogan consists of type II diabetics moderately and well-controlled (HbA1c 6-7.5\%) with a mean duration of disease of 7.5 years and a healthy control group. Augmentation of the maxilla was performed by guided bone regeneration with autologous bone from the mandibular ramus harvested by bone scrapers, a synthetic bone substitute, and collagen membrane. The result after 1 year is that patients with HbA1c 
levels $<7.5 \%$ may undergo staged guided bone regeneration securely [16]. The other study consisted of a larger group of type II diabetic patients and healthy control which were treated with simple or advanced implant therapy. The authors conclude that well- to fairly wellcontrolled diabetic patients with a mean HbA1c of $7.2 \%$ had the same overall survival rate as controls in conventional and advanced implant therapy. No difference was seen when looking at bone resorption [23].

\section{Influence of quality of glycemic control}

When looking at the question, if diabetes is a risk factor for dental implants, it is not sufficient to decide having diabetes or not. The greater the impact of diabetes, the worse the patient handles with glycemic control. In international studies, the percentage of glycosylated hemoglobin is an indicator for glycemic levels from previous 6-8 weeks. Unfortunately, many studies do not provide data of HbA1c. Some authors call their patient "under well control" or "poorly controlled," without representing any definition. Our search identified seven studies with a clear definition of different qualities of glycemic control by HbA1c. Three defined HbA1c 6-8 \% as good, 8-10\% as moderately, and $>10 \%$ as poorly controlled. Two studies called HbA1c $<8 \%$ better and $>8 \%$ poorly controlled and another $<7 \%$ well, 7-9 \% moderately, and $>9 \%$ poorly controlled. While four studies conclude better implant survival and less peri-implant complications in the well-controlled group $[8,10,14,17]$, the three others see no difference in implant success even in the poorly controlled patients $[9,15,23]$. The study of Khandelwal treated exclusively patients with poor glycemic control (HbA1c 7.5-11.4 \%) and had $98 \%$ implant survival, after 4 months; therefore, he concluded that implant therapy is successful even in poorly controlled diabetes [19].

\section{Influence of duration of diabetes disease}

It is plausible that with extended duration of diabetes, the systemic side effects increase. However, the influence of duration of the disease on implant surgery outcome is only very little examined. Most of the included studies (17 of 22) provided no data about duration since diagnosis of diabetes. In five studies, these data were given, but only two of them analyzed the influence on the implant survival. While Olsen concludes that the duration of diabetes may be associated with implant failure [26], Tawil says that implant survival is independent from diabetes duration [23].

\section{Influence of supportive therapy}

Although there is some controversy over the use of antibiotics in healthy patients, these are recommended in diabetic patients in implant surgery. The reason is the impaired immune system, which can lead to wound infections and healing complications. Some authors indicate the administration of antibiotics for 5-7 days postoperatively; others support the view that there is no significant reduction of wound infection when using antibiotics more than 1 day after surgery. Our literature search resulted in one prospective study that shows a clear benefit using preoperative antibiotics in both type II diabetics and non-diabetics. For implants in the nontype II diabetic group, survival for those implants placed with preoperative antibiotics was $4.5 \%$ higher than implants not provided coverage at placement surgery. This improvement in survival was even greater $(10.5 \%)$ for those in the type II diabetic group. These outcomes are clinically important and should be considered clinically significant [22]. But the authors do not describe which antibiotic they used and how long it was administered.

There was a large improvement in implant survival in the type II diabetic patients when chlorhexidine (CHX) (95.6\%, 4.4\% failures) was used at the time of implant placement, as compared to when $\mathrm{CHX}$ was not used (86.5\%, $13.5 \%$ failures). This difference in survival (9.1\%) was large enough to be considered clinically significant but was not found in the non-type II diabetic patient. For the non-diabetic group, survival increased only slightly when CHX was used (94.3\%, $5.7 \%$ failures), compared to when CHX was not used (91.8\%, $8.2 \%$ failures) $[22,26]$.

\section{Conclusions}

The literature included to this review is very heterogeneous concerning the investigated objects, methods, and conclusions. Diabetes is a group of metabolic diseases in which there are high blood sugar levels over a prolonged period. When looking at the complications and side effects resulting from diabetes, it is important to know which type of diabetes the patient suffers from, if there is any therapy, which kind of therapy, the grade of glycemic control, and duration of the disease. The previously described micro- and macroangiopathies develop with the duration and repetitions of elevated glycemic periods. In most studies, these information are missing and there is only a dichotomy classification of diabetes or healthy. Most studies include patients with wellcontrolled diabetes, and there is no or little effect on implant survival. Many authors conclude that prospective long-time studies are needed to answer the issues. On the other hand, it would be non-ethical to observe patients with poor glycemic control, because healththreatening systemic side effects developed.

Analyzing the available studies, we conclude as follows:

Dental implants are safe and predictable procedures for dental rehabilitation in diabetics. The survival rate of implants in diabetics does not differ from the survival rate in healthy patients within the first 6 years, but in 
the long-term observation up to 20 years, a reduced implant survival can be found in diabetic patients. Patients with poorly controlled diabetes seem to have delayed osseointegration following implantation. After 1 year, there is no difference between diabetic and healthy individuals, not even to the poorly controlled HbA1c. Therefore, we recommend avoiding immediate loading of the implants. In the first years after implant insertion, there seems to be no elevated risk of peri-implantitis; but in the long-term observation, peri-implant inflammation seems to be increased in diabetic patients. Therefore, a risk-adapted dental recall is helpful to detect early signs of gingivitis, which can easily be treated by dental/implant cleanings to avoid serious peri-implant infection. We found some hints that good glycemic control improves osseointegration and implant survival. Therefore, and to avoid other long-term side effects, the practitioner should ask for the HbA1c and if necessary improvement of antidiabetic therapy should be aimed. In the literature, we found no evidence that bone augmentation procedures like guided bone regeneration and sinus lifts have a higher complication and failure rate in patients with well- to fairly well-controlled diabetes. To improve implant survival and reduce postoperative complications, supportive therapy consisting of prophylactic antibiotics and chlorhexidine mouth rinse is recommended.

\section{Competing interests}

Hendrik Naujokat, Burkhard Kunzendorf and Jörg Wiltfang declare that they have no competing interests.

\section{Authors' contributions}

$\mathrm{HN}$ has done the data analysis and has written the manuscript. BK has managed the literature search and collected the original literature. JW is the head of the project and developed the project. He revised the manuscript. All authors read and approved the final manuscript.

\section{Acknowledgements}

The authors appreciate the technical support by Andreas Reinhardt Department for Oral and Maxillofacial Surgery University Hospital Kiel.

\section{Funding}

The study is funded by the German Association of Dental Implantology (Deutsche Gesellschaft für Implantologie im Zahn-, Mund- und Kieferbereich e.V.).

Received: 24 October 2015 Accepted: 5 February 2016

Published online: 11 February 2016

\section{References}

1. Moraschini V, Poubel LA, Ferreira VF, Barboza Edos S. Evaluation of survival and success rates of dental implants reported in longitudinal studies with a follow-up period of at least 10 years: a systematic review. Int J Oral Maxillofac Surg. 2015;44(3):377-88.

2. Khader YS, Dauod AS, El-Qaderi SS, Alkafajei A, Batayha WQ. Periodontal status of diabetics compared with nondiabetics: a meta-analysis. J Diabetes Complications. 2006;20(1):59-68.

3. Abiko Y, Selimovic D. The mechanism of protracted wound healing on oral mucosa in diabetes. Review. Bosn J Basic Med Sci. 2010;10(3):186-91.

4. Danaei G, Finucane MM, Lu Y, Singh GM, Cowan MJ, Paciorek CJ, et al. National, regional, and global trends in fasting plasma glucose and diabetes prevalence since 1980: systematic analysis of health examination surveys and epidemiological studies with 370 country-years and 2.7 million participants. Lancet (London, England). 2011;378(9785):31-40.

5. Chrcanovic BR, Albrektsson T, Wennerberg A. Diabetes and oral implant failure: a systematic review. J Dent Res. 2014;93(9):859-67.

6. Moher D, Liberati A, Tetzlaff J, Altman DG. Preferred reporting items for systematic reviews and meta-analyses: the PRISMA statement. PLoS Med. 2009;6(7):e1000097.

7. Viswanathan M, Ansari MT, Berkman ND, Chang S, Hartling L, McPheeters LM, Santaguida PL, Shamliyan T, Singh K, Tsertsvadze A, Treadwell JR. Assessing the risk of bias of individual studies in systematic reviews of health care interventions. Agency for Healthcare Research and Quality Methods Guide for Comparative Effectiveness Reviews. March 2012. AHRQ Publication No. 12- EHC047-EF. Available at: http://www.effectivehealthcare. ahrq.gov/ehc/products/322/998/MethodsGuideforCERs_Viswanathan _ IndividualStudies.pdf

8. Oates TW, Dowell S, Robinson M, McMahan CA. Glycemic control and implant stabilization in type 2 diabetes mellitus. J Dent Res. 2009;88(4):367-71.

9. Oates Jr TW, Galloway P, Alexander P, Vargas Green A, Huynh-Ba G, Feine J, et al. The effects of elevated hemoglobin A(1c) in patients with type 2 diabetes mellitus on dental implants: survival and stability at one year. Jm Dent Assoc. 2014;145(12):1218-26.

10. Aguilar-Salvatierra A, Calvo-Guirado JL, Gonzalez-Jaranay M, Moreu G, Delgado-Ruiz RA, Gomez-Moreno G. Peri-implant evaluation of immediately loaded implants placed in esthetic zone in patients with diabetes mellitus type 2: a two-year study. Clin Oral Implants Res. 2015;27(2):156-61.

11. Daubert DM, Weinstein BF, Bordin S, Leroux BG, Flemming TF. Prevalence and predictive factors for peri-implant disease and implant failure: a crosssectional analysis. J Periodontol. 2015;86(3):337-47.

12. Ferreira SD, Silva GL, Cortelli JR, Costa JE, Costa FO. Prevalence and risk variables for peri-implant disease in Brazilian subjects. J Clin Periodontol. 2006;33(12):929-35.

13. Turkyilmaz I. One-year clinical outcome of dental implants placed in patients with type 2 diabetes mellitus: a case series. Implant Dent. 2010;19(4):323-9.

14. Gomez-Moreno G, Aguilar-Salvatierra A, Rubio Roldan J, Guardia J, Gargallo J, Calvo-Guirado JL. Peri-implant evaluation in type 2 diabetes mellitus patients: a 3-year study. Clin Oral Implants Res. 2014;26(9):1031-5.

15. Dowell S, Oates TW, Robinson M. Implant success in people with type 2 diabetes mellitus with varying glycemic control: a pilot study. J Am Dent Assoc. 2007;138(3):355-61. quiz 97-8.

16. Erdogan O, Ucar Y, Tatli U, Sert M, Benlidayi ME, Evlice B. A clinical prospective study on alveolar bone augmentation and dental implant success in patients with type 2 diabetes. Clin Oral Implants Res. 2014;26(11):1267-75.

17. Ghiraldini B, Conte A, Casarin RC, Casati MZ, Pimentel SP, Cirano FR, et al. Influence of glycemic control on peri-implant bone healing: 12-month outcomes of local release of bone-related factors and implant stabilization in type 2 diabetics. Clin Implant Dent Relat Res. 2015. doi:10.1111/cid.12339. [Epub ahead of print]

18. Alsaadi G, Quirynen M, Komarek A, van Steenberghe D. Impact of local and systemic factors on the incidence of oral implant failures, up to abutment connection. J Clin Periodontol. 2007;34(7):610-7.

19. Khandelwal N, Oates TW, Vargas A, Alexander PP, Schoolfield JD, Alex McMahan C. Conventional SLA and chemically modified SLA implants in patients with poorly controlled type 2 diabetes mellitus - a randomized controlled trial. Clin Oral Implants Res. 2011;24(1):13-9.

20. Anner R, Grossmann Y, Anner Y, Levin L. Smoking, diabetes mellitus, periodontitis, and supportive periodontal treatment as factors associated with dental implant survival: a long-term retrospective evaluation of patients followed for up to 10 years. Implant Dent. 2010;19(1):57-64.

21. Busenlechner D, Furhauser R, Haas R, Watzek G, Mailath G, Pommer B. Long-term implant success at the Academy for Oral Implantology: 8year follow-up and risk factor analysis. J Periodontal Implant Sci. 2014; 44(3):102-8.

22. Morris HF, Ochi S, Winkler S. Implant survival in patients with type 2 diabetes: placement to 36 months. Ann Periodontol. 2000;5(1):157-65.

23. Tawil G, Younan R, Azar P, Sleilati G. Conventional and advanced implant treatment in the type II diabetic patient: surgical protocol and long-term clinical results. Int J Oral Maxillofac Implants. 2008;23(4):744-52.

24. Moy PK, Medina D, Shetty V, Aghaloo TL. Dental implant failure rates and associated risk factors. Int J Oral Maxillofac Implants. 2005;20(4):569-77. 
25. Peled M, Ardekian L, Tagger-Green N, Gutmacher Z, Machtei EE. Dental implants in patients with type 2 diabetes mellitus: a clinical study. Implant Dent. 2003;12(2):116-22.

26. Olson JW, Shernoff AF, Tarlow JL, Colwell JA, Scheetz JP, Bingham SF. Dental endosseous implant assessments in a type 2 diabetic population: a prospective study. Int J Oral Maxillofac Implants. 2000;15(6):811-8.

27. Fiorellini JP, Chen PK, Nevins M, Nevins ML. A retrospective study of dental implants in diabetic patients. Int J Periodontics Restorative Dent. 2000;20(4):366-73

\section{Submit your manuscript to a SpringerOpen ${ }^{\circ}$ journal and benefit from:}

- Convenient online submission

- Rigorous peer review

- Immediate publication on acceptance

- Open access: articles freely available online

- High visibility within the field

- Retaining the copyright to your article

Submit your next manuscript at $>$ springeropen.com 